\title{
Prices, institutions and the coordination of economic growth
}

\author{
Paolo Ramazzotti
}

\section{ramazzotti@unimc.it}

\section{Growth as a contested goal}

The aim of this paper is to point out that there are two ways to discuss economic growth as a policy goal. They reflect two views of economic policy and, more generally, of economic theory. The main issue that distinguishes them is how economic activity is coordinated and assessed. The first one focuses on price-centered coordination. The economy, which, according to this strand of thought, boils down to the market, is conceived of as a closed system: once endowments, preferences and technology - or patterns of technological change - are given, economic agents choose according to the information that prices provide. Doubtless, there may well be shortcomings in the proper functioning of prices and it may be necessary to resort to institutions ${ }^{i}$ to make up for these shortcomings. Their function, however, is to complement prices.

The alternative view is that coordination of the economy does not and cannot occur only through prices. This is quite independent of possible shortcomings in the way prices function. The main idea is that the economy is an open system. Its interaction with the natural and social systems it is situated in implies that it functions according to an institutional framework that depends on society's history. At the same time, the economy affects the natural and social environments it is a part of. It is therefore impossible to understand the coordination of the economy independently of society. More generally, although prices coordinate along with institutions, they do not reflect natural scarcity or preferences. Institutions do not merely complement prices: they regulate the way they function. 
These two different approaches reflect different views of the economy and of society. They lead to different views with regard to what growth involves and how to assess it, thus also with regard to the actions that governments can and should take ${ }^{i i}$. Ultimately, they lead to different conclusions with regard both to what pattern of growth is possible and required and to how such a growth can be pursued.

The paper is structured as follows. Sections 2 and 3 depict the main features of the price-centered and institution-centered approaches, respectively. Section 4 discusses the differences between the two strands of thought. It then emphasizes what they imply with respect to performance assessment and policy. Section 5 focuses on an important implication of the discussion. Briefly, in so far as the two approaches acknowledge the need for a government action of some kind, they raise an accountability and democratic supervision issue. In order for people to supervise governments, government action must guarantee them with a range of basic social, as well as civil and political, rights. Thus, a major decision concerning how to pursue growth has to do with those rights. Section 6 provides some concluding remarks.

\section{Price-centered coordination}

The first approach conceives of the economy as a market. It includes neoclassical and Austrian scholars, including their offshoots: Monetarists, New Classicals, New Growth Theorists, New Institutionalists, Constitutional Economists, Ordoliberals, etc. The goal economic agents pursue is the satisfaction of needs through consumption. Prices are an indicator of: the goods and services that they can consume; the resources they have, which allow them to gain access to those goods; the technology that allows them to transform those resources into the desired goods; the preferences that they have relative to the available goods and services and, consequently, relative 
to the potential use of available resources ${ }^{\text {iii }}$. Given these premises, prices provide economic agents with all the information they need in order to achieve their goal. Cultural, societal or other types of circumstances may affect the economy. For instance, religious institutions may favor beliefs and ideologies that slow down or even prevent economic growth (North 1990). According to the pricecentered approach, however, they do not change the basic function of prices as the metric to value growth and the means to pursue it.

Individuals pursue self-interest in terms of consumption and profit. The means to achieve this general goal are production and exchange. According to neoclassical theory, if a range of conditions holds and prices work properly, resources are used in the best of ways: the outcome is Pareto optimal. Such allocative efficiency also allows achieving the highest rate of economic growth, that is, more goods and services available to consumers. According to Austrian theory, agents must be able to identify solutions to problems. This dynamic efficiency will eventually lead to changes in the composition of output and in relative prices. Despite these different notions of efficiency, the aim of the economy is to provide price-denominated resources.

Efficiency conditions may not hold. Market failures - externalities, public goods, informational asymmetries, economies of scale - are impediments to allocative efficiency ${ }^{\text {iv }}$. A major theoretical problem is how to deal with them. There are basically three approaches. The first one focuses on a discretional public policy. It points out that, based on an explicit or implicit social welfare function, the government can introduce measures that either allow the market to operate properly or make up for the shortcomings that market failures lead to. This is the standard textbook approach whose best-known policy tool is the Pigouvian tax. The second one points out that economic agents are often able to devise solutions to market failures that do not require any public action: a typical example is firms (Coase 1937; Williamson 1985, 2000). Market solutions to market failures are not always possible, however. Government action is sometimes required: a typical example is 
externalities, which require that someone assign property rights before market transactions can take place. Under these circumstances, the claim is that any action of this type should be assessed properly by considering not only the costs that market failures imply but also those determined by public action. In this perspective, scholars who follow this approach suggest measures that reduce or eliminate the shortcomings determined by market failures while minimizing public action (Coase 1960). The third approach is less concerned with comparing the costs that specific measures involve. Its main tenet is that policy makers seek their self-interest in terms of votes, so they neglect the costs of public action and are, therefore, unlikely to pursue efficiency (Buchanan 1991).

Despite differences within these approaches, a common assumption is that prices are the main coordinating device. They are the metric that measures goals - consumption, profit and growth and the means to pursue them, through production and exchange. Institutions that make them function appropriately may be exogenous, as in the case of the government, or endogenous, as when firms arise to reduce transaction costs. They are required, however, only in so far as prices are not working properlyv

3. Institution-centered coordination: general features

The second strand of thought that we are concerned with includes Original Institutionalists, Post Keynesians, Marxists, Regulation and Social Structures of Accumulation theorists, etc. According to this strand, economic relations - i.e. activities that provide for the material reproduction of society - are strictly related to the social reproduction of society: its power relations, its culture and, more generally, its institutions. The society they are a part of is rooted in a historical process. In particular, institutions are not only solutions to problems that arise within the economy. While the latter 
certainly exist, other institutions depend on the myriad features of society and nonetheless determine the overall setup of the economy.

An implication of the interdependence between economic and other elements is that markets are neither an everlasting feature of all economic systems nor the outcome of some teleological progress that the evolution of the economy ought to have achieved. Contracted exchange and the pervasive role of relative prices are a historically determined feature of modern economies, but they are only a part of an economic and social system, which does not, and cannot, have the efficiencyrelated connotations that the price-centered approach attributes it. This means that, contrary to the first approach, prices cannot function as a unique metric to assess economic growth.

A second aspect is that coordination, here, has a looser connotation than in the price-centered approach. It does not require that every action be made consistent with all others. It only determines some degree of consistency: coordination may be local and it may be temporary. This is why growth may occur along with unemployment, why wealth may grow along with social unrest and why economic and financial crises occur.

A third aspect is that the economy is socially segmented. Different groups, classes, communities and organizations exist because, given the absence of a general economic coordinating instance such as prices, economic actors are not united by a single class of transactions. Their different interests co-exist and are attended to in a variety of ways: habits (as for savings), bandwagon behavior (as for investment), propaganda (as for advertisements), strikes (as for distributional conflict), etc. Social segmentation also exists because people view their lives not only in terms of provisioning. They self-identify and organize themselves in relation to other goals as well (Sen 1986). This is a reflection of the systemically open nature of the economy (Kapp 1976).

While the price-centered approach accounts for production and exchange in terms of technology and prices, the institution-centered one provides a more varied picture. Different modes of 
production are possible, depending on the specific social relations among different groups of economic actors. Some concerns, and the institutions they are related to, dominate others and impose a specific type of coordination. The institutionally determined goals of the dominant concerns may constrain the material reproduction of society. They may eventually prevail over societal values (Polanyi 1944).

The existence of multiple actors implies that the material reproduction of a society may occur concurrently with various goals: power (Samuels, Tool 1989), profitability (Marx 1867/1990), rents (Keynes 1936). It is also subject to the constraints determined by existing institutions and the enabling myths they lead to ${ }^{\text {vi }}$ : gender discrimination, racist prejudices, etc. vii. These are the elements that provide for the distinction between, e.g., capitalism and feudalism or German capitalism and Mexican capitalism. Thus, means to achieve economic growth and, more generally, economic change include various elements, not just prices.

Given these features of the institution-based strand of thought, it is fairly easy to see that differences within it are greater than those within the price-centered one. The latter views prices as a unifying element, with institutions in a subsidiary position. The former assumes that many institutions exist and that they all affect the economy in one way or other. Depending on which institutions are assumed to prevail, different approaches may coexist within the institutioncentered view. The aim of the discussion that follows in the next section is to point out - in a less abstract way - what distinguishes the institution-centered view from the price-centered one. It will therefore consider some themes that many institution-centered economists are likely to share. It does not claim that all of them do.

4. Institution-centered coordination: a more detailed picture 
Contrary to the price-centered strand of thought, in the institution-centered one markets need not encompass the economy as a whole. It is not just that other economic activities exist that are not strictly based on contracted exchange - non-profit organizations, public agencies, etc. - thereby preventing it from fulfilling its allocative function in the best of ways. The goals and the constraints that characterize a specific type of material reproduction of society assign markets a complementary, rather than an exclusive, role.

More specifically, a feature common to many institution-centered approaches to coordination is that the dominant feature of the economy we live in is not the mere demand for goods and services but the pursuit of money profit. The price-centered view is that the economy is based on the exchange of commodities for money in order to subsequently buy other commodities: a process of the Commodity-Money-Commodity (C-M-C) type. The alternative view is that a capitalist market economy is based on moneymaking. It generally is a process where money is advanced in order to buy commodities that, once transformed, are sold for a money profit: it is a process of the MoneyCommodity-Augmented Money (M-C-M') type ${ }^{\text {viii }}$.

If money profit is at the core of economic activity, growth must be consistent with profitability but it need not be consistent with serviceability. Veblen (1904) stressed that more profit is often achieved by producing less. It may also be inconsistent with the quality of life: social costs such as environmental pollution or workplace injuries depend on a disjuncture between private accounting - which is what business uses - and social accounting, which includes both the monetized and nonmonetized costs that business activities impose on society (Kapp 1971). This same disjuncture leads to the 'provisioning' of 'goods' that are bad for health and for security (Passas, Goodwin 2004). Finally, profitability may even forsake provisioning. This is what happens when money is made independently of production, in a Money-Augmented Money (M-M') process (Veblen 1908, Keynes 1936). It is also bound to happen when intensive agricultural production leads to soil degradation 
or when international trade leads to the paradox that a poor country with a hypoproteic diet supports a rich country's hyperproteic diet (Kapp 1976).

At this point of the discussion the question is whether the above disjuncture can be overcome through appropriate regulation. In this respect, institutionalist scholars (Bromley 1989, Commons 1924) have pointed out that no market can function unless it is organized by appropriate rules. Ownership, transactions, goods: market-related concepts such as these must be defined, thereby regulating the market's potential performance. How they are defined depends on circumstances that are preliminary to the very existence of a market. They are 'external' to the market. They act as exogenous variables. They are not naturally determined and, indeed, may be of different kinds: ownership may or may not include the possession of human beings, i.e. slavery; transactions may be carried out by one or by all genders; goods transacted may or may not include toxic drugs or guns.

These characteristics may support the contention by some price-centered scholars (Roepke 1960, Buchanan 1991, Vanberg 2001) that the main issue is to establish the rules that govern the market and then let relative prices carry out their coordinating function. Some general remarks are called for, however.

First, the way markets are arranged is not neutral for society. Whether children can work or must go to school, whether women are in a subordinate position or not: these choices inevitably feed back on how both the economy and society are organized. Ethical values are inevitably involved. They may not be the only determining elements, however. Since there is nothing natural about the rules that lead to a specific market organization, it is reasonable that those who can gain from a different arrangement - e.g. the freedom to sale guns - will attempt to achieve it, either by bypassing extant rules or by lobbying to change them ${ }^{\mathrm{ix}}$. Second, when a society decides that, say, children cannot buy guns, it is deciding that there is no general market where everything is transacted: Actual 
markets are restricted to only some types of transactions. When society decides that households, non-profit organizations or the welfare state are in charge of some aspects of provisioning, it is determining the boundaries of markets relative to the rest of the economy. When it taxes luxury goods and subsidizes books, it affects the composition of output. These considerations suggest that markets may concur to provisioning but that, since they are restricted to just a section of the economy, they are not complete. Consequently, even from a conventional perspective, there is no reason for them to be efficient or for prices to provide the information required to achieve some sort of order.

Third, in the discussion of price-centered coordination, we pointed out that prices are expected to have a twofold function. They are the means to achieve a community's goals and they measure its achievement. The institution-centered approach is different. Societal institutions - firms, trade unions, consumer associations, civil rights movements, etc. - determine the organization of the economy and how it functions. Based on their interaction, they determine their power relations and the system of rights that regulates the economy. Thus, however regulated, these economies can hardly be put on the same footing as those theorized by price-centered scholars. Quite to the contrary, "There are no such things as "true" costs or "correct" prices. There are only costs and prices which are a function of technology, subjective valuations and interests insofar as they are registered and valorized in the market and in politics. Costs are not ontologically given. They are generated by human beings in social processes on the basis of subjective valuations, technology and rights/power structures.' (Samuels, Schmid 1977: 226). It is no wonder, therefore, that these economies cannot but function differently. For instance, institution-centered scholars point out that, today, manufacturing firms in Western economies choose their output in relation to expected demand rather than by adapting to price changes. They keep their prices constant over a fairly long stretch 
of time, rather than adapting them to existing demand. Administered prices provide for consistency between expected demand and expected profit rather than equalizing supply and demandx.

These issues point out that, even when prices are allowed to coordinate economic activity, how they do so depends on rules that are determined according to non-price criteria. Prices may be a means to achieve given goals but what those goals are depends on a non-price metric.

Odd as it may seem, a careful look suggests that the price-centered approach must rely on nonprice criteria as well. In order to appreciate this issue, let us consider externalities within the pricecentrality approach. According to the social welfare function view, action such as a tax or a regulation may impose the cost of the externality correction on a specific industry or firm. Resources will be used less there and will be redistributed to other firms or industries because this will increase social welfare. Alternatively, action based on subsidies or different forms of regulation impose the cost on society as a whole. Who is supposed to bear the cost of the externality remains an open issue unless a metric other than price is used. This is precisely what underlies the social welfare function.

The New Institutionalist view appears to be simpler than the first one in that it dispenses with the welfare function. Since internalization allows costs to emerge out of transactions, the ideal solution is, in so far as possible, to re-establish price coordination in order to eliminate externalities. Despite this intuitive appeal, however, this approach is not as straightforward as it looks. Although a comparative cost assessment may allow single agents to minimize their costs, there is no reason to believe that this 'relative efficiency' is good for the community as a whole. There are two problems, here. First, is it acceptable for society that a human right such as health be treated like any commodity? In other terms, is it really the case that things like human rights are not subject to lexicographic preferences? Second, assuming that the answer to these questions is 'yes', the relative price set used would nonetheless be one that neglects the existence of an externality. Consider that 
the property right would have to be assigned to the party that can use the relevant resource in the most efficient way. This requires a comparison in terms of relative costs, which depends on the extant price set. The extant price set, however, is biased by the externality: it is not a price set that is conducive to efficiency. Is it appropriate to carry out the assessment with such a 'wrong' price set?

These considerations suggest that there is a general problem with these price-centered views of economic coordination: efficiency is not a robust concept. Once we realize that we cannot achieve an ideal Walrasian general equilibrium, it is not clear how to achieve allocative efficiency. Under these circumstances, the claim that the latter is a preliminary condition for, or a policy criterion to guide economic growth is neither right nor wrong: it is simply a conceptually vague statement ${ }^{\mathrm{xi}}$. Just as with the traditional welfare function view, a non-price metric is required to choose what the preferred arrangement should be.

Let us consider the unreliability of policy makers claim, which undermines the possibility of a decision over who should bear the cost of offsetting an externality. The claim draws on practical experience. Indeed, it is often the case that politicians pursue goals other than the community's. This observation, however, warrants neither a generalization nor a hasty conclusion. It does not warrant a generalization because, in fact, self-interest may involve different possible goals, ranging from 'here and now' monetary goals to the long-run satisfaction that comes from doing one's duty or from arranging things in the best of ways ${ }^{x i i}$. How self-interest impinges upon the behavior of policy makers should be investigated rather than taken for granted. Henry (2017) for instance, acknowledges that, despite some important exceptions, 'war mongers, mass murderers, liars, hypocrites, opportunists - in short, anti-social individuals - end up as the dominant force in determining the nature and direction of society' (ibid.: 250), thereby including political rulers along with economic ones, but he does suggest that this circumstance is most likely related to inequality. 
The observation should also avoid the hasty conclusion that, if politicians are corrupt, business conduct is better. In so far as a restricted self-interest is possible, it may apply to business just as well as to government: consider the case of Enron in the U.S. Even a less restrictive - not illegal self-interest may be troublesome in economic activity. Business behavior in a money manager capitalism is most likely to focus on short-term goals and to prefer financial gains to the detriment of manufacturing and employment (Lazonick, O'Sullivan 2000). The main issue, however, is that whether the distinction between private and social accounting exists can be decided only according to a criterion that transcends prices.

Despite its shortcomings, the "unreliability of policy makers" approach does suggest that the polity should be organized in a manner that enhances accountability. This is an issue with important implications for how the polity is organized. While this suggests that the topic is more pertinent to political science and to legal studies, there is an economic aspect that needs to be discussed. This is the topic of the next section.

5. Policy, accountability and democracy

The discussion in the previous sections suggests that scholars from the institution-centered approach are not the only ones who claim that some kind of policy is required. Despite differences within the price-centered strand of thought, many of its scholars tend to reach the same conclusion. Along with the standard accounts, whereby policy must improve allocative efficiency and, possibly, comply with some social constraints, recent developments have reinforced the scope for public action. Indeed, while liberalism theorized that there should be no government intervention, neoliberalism acknowledges that laissez faire is no longer appropriate. Active government action is considered necessary to make price-centered coordination possible. This is particularly the case 
with welfare to work policy, which actively aims to make the labor market operate just like a standard commodity market. Workers may well need some time to find a job and they should be subsidized in the meantime but they will eventually have to adapt to what firms demand, with the wage equating labor supply and labor demand. A similar approach appears with welfare policy. Neoliberals generally acknowledge that public solidarity is necessary when people are unable to take care of themselves. They claim, however, that in general welfare entitlements - that is, the public provision of services to guarantee education, health, pensions, etc. - provide a negative incentive. People who benefit from free services will not care to work. In order for prices to coordinate the economy, the welfare state must not distort the coordinating function of prices. Therefore, people must pay for these services.

Based on these premises, growth and, in general, the desired performance of the economy depend on a policy that structures the economy so that prices can coordinate it. It includes removing obstacles to price flexibility, making up for shortcomings such as market failures and, at the very least, providing positive and negative incentives. It also involves a high degree of commodification of the labor force.

Note that the neoliberal approach considers prices as the means to achieve growth and as the metric to assess it but, at the same time, it assumes that policy makers must establish the institutions that allow prices to play this twofold role. In order to establish those institutions, policy makers cannot rely on prices. Prices are supposed to result from those institutions, so they cannot precede them. Since policy makers must transcend prices, it is not possible to assess their action in terms of this metric. In turn, this reinstates the reliability issue: How are policy makers to account for their action?

Let us now consider the institution-based approach. Here, policy is not restricted to making prices work. Prices are neither the coordination nor the performance metric. Policy makers must actually 
decide what the economy is to work for, i.e. what priorities it must pursue. Growth must be qualified in relation to goals such as may be full employment, a smaller ecological footprint or the protection of basic human rights such as those outlined in the Universal Declaration of Human Rights ${ }^{\text {xiii }}$. Here too, just as in the price-centered approach, policy makers must be accountable for what they are expected to do. Contrary to the price-centered approach, however, they must also be able to understand and interpret what the community requests - what goals it pursues - and put it into effect by formulating a consistent set of measures. Consequently, they must also be accountable for correctly expressing collective goals.

Democratic deliberation and control is a broad issue. It involves various disciplines and its proper treatment obviously lies beyond the boundaries of this paper. What is important, here, is that, in order to be effective, democracy must be supported by appropriate economic conditions. The main issue is that people must be able to participate in the democratic process.

In order to discuss these conditions, let us dismiss some extremely simplifying - and definitely false - assumptions that most economics textbooks formulate about individuals: that they have complete information; that they can process it (Simon 1976); that they can assess it in the light of a complete and consistent set of preferences (Sen 1982). In so doing, we need to acknowledge that, in order to 'have the last word', people must be capable to decide. They must have access to the information they need, they must be able to make sense of that information and to elaborate on it through interaction with others. These conditions lead to a set of other requirements. People must receive the schooling they need to become conscious citizens. No circumstances must systematically prevent them from taking part in this democratic process. Basic requirements include health, employment, working conditions, income, participation in the community life.

Requirements for the proper functioning of a democracy imply what appears to be an open issue for the price-centered approach, especially for its neoliberal wing. The economy ends up having two 
types of coordination: prices and the institutions that underlie democracy ${ }^{\mathrm{xiv}}$. Either we constrain price coordination in order to meet the economic requirements for a full-fledged democracy or we succeed in allowing prices to operate freely. In the latter case, the economy may fail to meet the economic conditions for democratic participation, thereby making an authoritarian regime possible. The possible inconsistency between the two forms of coordination is not limited to the establishment of the economic conditions for democracy, however. A democratic regime implies that people are free to decide, which means that they may choose something that is incompatible with price coordination. It is no wonder that Hayek, a most fervent supporter of price-centered coordination, had mixed feelings about democracy ${ }^{x v}$.

The relation between economic policy and democracy is somewhat problematic for the institutioncentered approach as well. Although an appropriate policy is possible that meets the economic requirements for democracy, the absence of those very requirements may prevent such a policy from being enacted. In order to understand this possible vicious circle, recall that coordination of the economy depends, directly or indirectly, on circumstances - power relations, values, knowledge - that emerge from societal relations. In practice, this means that coordination of the economy is strictly related to how democracy works, thus to the coordination of society. Economic growth is not a merely technical issue concerning the coordination of economic activity. It is strongly related to the relation between democracy and the social reproduction of society.

\section{Concluding remarks}

It is generally taken for granted that income growth is an important economic goal and that the real issue is how to pursue it. This view is subject to debate. The paper argued that growth without further qualifications may be a reasonable goal only if we conceive of the economy in a very specific 
way: a market coordinated by prices and, possibly, by institutions that make up for price-related shortcomings; an assessment of economic performance that relies on prices as the only appropriate metric.

The above approach has little to say about the quality of life. On substantive grounds, if market failures are internalized, the quality of life itself - including fundamental human rights - becomes a commodity. On formal grounds, any price set that reflects the existence of market failures results in a biased allocation, thereby precluding what ought to be an efficient outcome. If the quality of life is not just a matter of prices, some kind of government action is necessary.

An alternative to the price-centered view is one where the economy is coordinated not only by prices but also by a range of institutions that may emerge as a solution to market-specific problems but may also be determined by other circumstances: social power relations, societal values, knowledge, etc.. Under these circumstances, growth can be assessed in terms of different metrics - money profit, power, rents, the quality of life, etc. - depending on the goals of the different actors that pursue it.

The means to achieve growth may also have little to do with prices but depend on these metrics. Following this perspective, whether growth is important or not depends on the goals pursued and on the money and non-money costs that it involves. In turn, these depend on which institutions prevail.

While, according to the price-centered approach, policy makers must be accountable for achieving growth through price-coordination, possibly subject to some social constraint, the institutioncentered one considers policy makers accountable both for the choice of the desired type of growth and for its achievement. If we look at this issue from the perspective of the constraints to economic growth, the price-centered approach implies that there is only one type of growth - which reflects prices, thus preferences. Possible constraints depend either on 'internal' circumstances that prevent 
prices from operating efficiently - as is typically the case with 'market failures' - or on 'external' circumstances - such as the risk of environmental disruption or the guarantee of a quality of life threshold - that interfere with prices. The institution-centered approach, on the other hand, dismisses the distinction between 'internal' and 'external', as well as the existence of a unique metric for growth. Different types of growth are therefore possible. They depend on power relations but also on value judgments concerning societal priorities. Given these priorities, appropriate institutions - e.g. appropriate rules - must be devised to achieve the qualitatively and quantitatively desired growth.

Government action implies accountability, independently of the assumed type of coordination. If accountability is to be attained in a democratic system, all citizens must be able to actively participate in the organization of the polity. This means that the government must guarantee a set of rights that underlie this participation.

This intermediate policy goal clashes with rigorous price-centered views in that it involves government action independently of prices. Neoliberal policies follow this rigorous approach while acknowledging the role for public policy. They therefore fail to ensure accountability and are biased towards an authoritarian view of governments.

The importance of participation is consistent with the general policy-oriented stance of the institution-centered approach. This approach, however, posits a strong link between the material and the social reproduction of society. Thus, the characteristics of economic growth strongly depend on social circumstances and on how they interact with the polity. According to this approach, the features of growth and the nature of democracy are interdependent.

Bibliographical references 
Basu, K. (2017). Discrimination as Focal Point: Markets and Group Identity, Forum for Social Economics, XLVI, 128-138

Bromley, D.W. (1989). Economic Interests and Institutions - The conceptual foundations of public policy, New York: Blackwell

Buchanan, J.M. (1991). Constitutional Economics, Oxford: Basil Blackwell

Caldwell, B., \& Montes, L. (2014). Friedrich Hayek and His Visits to Chile, Center for the History of Political Economy CHOPE. Working Paper No. 2014-12.

Coase, R.H. (1937). The Nature of the Firm, Economica, 4, 386-405; also in R.H. Coase The Firm, the Market, and the Law, Chicago: The University of Chicago Press, 1988

Coase, R.H. (1960). The Problem of Social Cost, The Journal of Law and Economics 3, 1-44; also in R.H. Coase The Firm, the Market, and the Law, Chicago: The University of Chicago Press, 1988

Commons, J.R. (1924). Legal Foundations of Capitalism, New York: Macmillan

Dugger, W.H., \& Sherman, H.J. (2000). Reclaiming Evolution. A dialogue between Marxism and institutionalism on social change, London: Routledge

Farrant, A., McPhail, E., \& Berger, S. (2012). Preventing the 'Abuses' of Democracy: Hayek, the 'Military Usurper' and Transitional Dictatorship in Chile?, American Journal of Economics and Sociology, $713,513-538$

Goodwin, N. (2014). The human element in the new economics: a 60 -year refresh for economic thinking and teaching, real world economics review, 68, 98-118

Henry, J.F. (2017). Brutus Is an Honorable Man, Journal of Economic Issues, LI(2), 247-261

Hodgson, G.M. (2006). What Are Institutions?, Journal of Economic Issues, XL(1), 1-25

Jo, T-H. (2016). What If There Are No Conventional Price Mechanisms, Journal of Economic Issues, $L(2), 327-344$

Kapp, K.W. (1971). The Social Costs of Private Enterprise, New York: Schocken Books 
Kapp, K.W. (1976). The Open-System Character of the Economy and its Implications, K. Dopfer (ed), Economics in the Future: Towards a New Paradigm, London: Macmillan, 90-105

Keynes, J.M. (1936). The General Theory of Employment, Interest and Money, London: Macmillan Keynes, J.M. (1973). A Monetary Theory of Production, D. Moggridge (ed), Collected Writings of John Maynard Keynes, vol. XIII, London: Macmillan, 408-411

Lazonick, W. \& O'Sullivan, M. (2000). Maximizing shareholder value: a new ideology for corporate governance, Economy and Society, 29(1), 13-35

Marx, K. (1867/1990). Capital, Volume I., London: Penguin Books.

North, D.C. (1990). Institutions, Institutional Change and Economic Performance, Cambridge: Cambridge University Press

Passas, N. \& Goodwin, N. (eds) (2004). It's Legal but it Ain't Right. Harmful Social Consequences of Legal Industries, Ann Arbor: The University of Michigan Press

Polanyi, K. (1944). The Great Transformation, New York: Holt, Rinehart \& Winston

Roepke, W. (1960). A Humane Economy. The Social Framework of the Free Market, Chicago: Henry Regnery Company

Samuels, W.J. (1977). Technology vis-à-vis institutions in the JEl: A suggested interpretation, Journal of Economic Issues, 11, 871-895

Samuels, W.J. \& Schmid, A.A. (1997). The Economy as a Process of Valuation, Cheltenham: Elgar Samuels, W.J. \& Tool, M.R. (eds) (1989). The Economy as a System of Power, Oxford: Transaction Publishers

Schumpeter, J.A. (1934/2011). The Theory of Economic Development. An Inquiry into Profits, Capital, Credit, Interest, and the Business Cycle, Oxford: Transaction Publishers

Sen, A.K. (1982). Rational Fools: A Critique of the Behavioural Foundations of Economic Theory, Choice, Welfare and Measurement, Oxford: Basil Blackwell, 84-106 
Sen, A.K. (1986). Rationality, Interest, and Identity A. Foxley, M.S. McPherson, G. O'Donnel (eds), Development, Democracy and The Art of Trespassing. Essays in Honor of Albert O. Hirschman, Notre Dame (Indiana): University of Notre Dame Press, 343-353

Simon, H.A. (1976). From Substantive to Procedural Rationality, in S.J. Latsis (ed), Method and Appraisal in Economics, Cambridge: Cambridge University Press, 129-148

Sraffa, P. (1960). Production of Commodities by Means of Commodities. Prelude to a Critique of Economic Theory, London: Cambridge University Press

Vanberg, V.J. (2001). The Constitution of Markets. Essays in Political Economy, London: Routledge Veblen, T. (1904). The Theory of Business Enterprise, New York: Schribner's

Veblen, T. (1908). On the Nature of Capital: Investment, Intangible Assets, and the Pecuniary Magnate, The Quarterly Journal of Economics, 23 (1), 104-136

Veblen, T. (1919). The Vested Interest and the State of the Industrial Arts, New York: B.H. Huebsch Veblen, T. (1921/2001). The Engineers and the Price System, Kitchener, ON (CA): Batoche Books Williamson, O.E. (1985). The Economic Institutions of Capitalism. Firms, Markets, Relational Contracting, New York: The Free Press

Williamson, O.E. (2000). The New Institutional Economics: Taking Stock, Looking Ahead, Journal of Economic Literature, Sept., 595-613

\footnotetext{
i "Institutions are systems of established and embedded social rules that structure social interactions" (Hodgson 2006: 18).

ii The term government is used in a broad sense. It includes both national and local bodies that carry out economic policy.

iii The price-centered strand of thought is generally based on the marginalist theory of value and distribution. The internal consistency of the theory has been questioned since Sraffa's (1960) book. It goes without saying that the marginalist authors tend to disregard this issue.
} 
iv Institutions, both endogenous and exogenous, may also prejudge efficiency (North 1990). They raise the same policy issues that market failures raise.

v Williamson (2000: 603) stresses this point: "Note that the common practice of condemning public bureaus because they have lower-powered incentives, more rules and regulations, and greater job security than a counterpart firm completely misses the point. These features have been deliberately crafted into the public bureau, thereby to make it better suited to govern some (especially difficult) transactions."

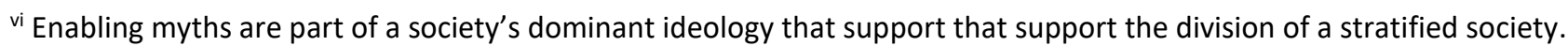
(Dugger, Sherman 2000: 70)

vii The distinction between goals, which are directly pursued, and constraints is not as sharp as it appears. An example of how profit and racism may go together is in Basu (2017).

viii The distinction between C-M-C and M-C-M' is in Marx (1867/1990) but similar considerations can be found in authors such as Veblen (1904, 1919/2001, 1921/2001), Keynes (1973) and Schumpeter (1934/2011).

ix This is important from a policy perspective. It is not enough to establish rules. Direct action is also required to deal with the intended and unintended consequences of reactive and proactive economic behavior.

x "That the going enterprise goes through a pricing procedure means that product prices are strategically determined and administered in order to generate target profits or retained earnings for it to remain ongoing or growing" (Jo 2016: 340).

${ }^{x i}$ The above vagueness is not sufficient to claim that the price-centered approach is flawed. It is sufficient, however, to suggest that the economic discourse should be open to different perspectives.

xii If everybody were to behave only according to their restricted self-interest, nobody would be reliable (Goodwin 2014). It is undoubtedly true that, for instance, even a law-enforcing body such as the police is corrupt in some countries. This is not the case everywhere, which accounts for the confidence people in other countries have in law enforcement and in the possibility to carry out their businesses.

xiii http://www.un.org/en/universal-declaration-human-rights/index.html, (accessed on 5 April 2018)

xiv These institutions are not like the ones whose existence the price-centered approach generally acknowledges. Contrary to the latter, they are functional to an alternative - and possibly "price-distorting" - coordination.

xv See Farrant, McPhail and Berger (2012); Caldwell and Montes (2014) provide a friendlier view, which, however, does not dismiss the issue. 